\title{
Quality of life and handgrip strength of HIV patients diagnosed with neurotoxoplasmosis
}

\section{Qualidade de vida e força manual em pacientes HIV com diagnóstico de neurotoxoplasmose}

\author{
Luiz Fernando Gouvêa-e-Silva ${ }^{1,2,3}$ \\ (D) https://orcid.org/0000-0002-1953-9175 \\ Cíntia Naira Souza de Lima ${ }^{2}$ \\ (D) https://orcid.org/0000-0002-5304-0052 \\ Kerolen Tayla Lima Fernandes ${ }^{2}$ \\ (1D https://orcid.org/0000-0001-6794-0185 \\ Silvania Yukiko Lins Takanashi ${ }^{2}$ \\ (D) https://orcid.org/0000-0002-6410-7160 \\ Marília Brasil Xavier 1,2 \\ (D) https://orcid.org/0000-0003-2706-3880
}

Abstract - HIV / AIDS epidemic continues to be a major public health problem, and when there is poor adherence to treatment, patients become susceptible to other infections such as toxoplasmosis. The aim of this study was to evaluate the handgrip strength and quality of life of HIV infected patients diagnosed with neurotoxoplasmosis. A cross-sectional study was conducted with $40 \mathrm{HIV}$-infected patients, with and without diagnosis of neuroxoplasmosis. Sociodemographic and clinical profile information was collected, and handgrip strength and quality of life were evaluated. Almost all patients of both groups used antiretroviral therapy. In the handgrip strength evaluation, no statistical difference was observed for the right and left hand between groups with and without neurotoxoplasmosis ( $p>0.05$ ). However, the classification of inadequate handgrip strength in the neurotoxoplasmosis group was significantly higher. In the quality of life domain, it was observed that financial concern had lower scores in the group with neurotoxoplasmosis $(\mathrm{p}=0.0379)$. It was observed that neurotoxoplasmosis showed no association with epidemiological, clinical, handgrip strength and quality of life variables. However, patients with neurotoxoplasmosis showed a trend towards lower muscle strength.

Key words: Acquired immunodeficiency syndrome; Cerebral toxoplasmosis; Hand strength; Quality of life.

Resumo - Atualmente a epidemia do HIV/Aids continua sendo um problema de saúde pública de ampla relevância, e quando não há uma boa aderência do paciente ao tratamento o mesmo torna-se suscetivel a outras infecçôes como a toxoplasmose. Objetivou-se avaliar a força de preensão manual e a qualidade de vida em pacientes infectados pelo HIV com diagnóstico de neurotoxoplasmose. Foi realizado um estudo transversal com 40 pacientes infectados pelo HIV, com e sem diagnóstico de neuroxoplasmose. Foram coletadas informaçôes sociodemográficas, perfil clínico e foram avaliadas a força de preensão manual e a qualidade de vida. Quase todos os pacientes de ambos os grupos utilizavam a terapia antirretroviral. Na avaliação de força de preensão manual não notou-se diferença estatística para a força manual direita e esquerda entre os grupos com e sem neurotoxoplasmose ( $p>0.05$ ). Contudo, a classificação de inadequado para a força manual no grupo com neurotoxoplasmose foi significativamente maior. Nos dominios da qualidade de vida, observou-se que a preocupação financeira apresentou menores escores no grupo com neurotoxoplasmose ( $p=0.0379$ ). Observou-se que a neurotoxoplasmose não demonstrou associação com as variáveis epidemiológicas, clínicas, da força manual e da qualidade de vida. Contudo os pacientes com neurotoxoplasmose apresentaram uma tendência para menor força muscular.

Palavras-chave: Força da mão; Qualidade de vida; Sindrome da imunodeficiência adquirida; Toxoplasmose cerebral.
1 Federal University of Pará. Graduate Program in Tropical Diseases. Belém, PA. Brazil.

2 State University of Pará. Center for Biological and Health Sciences. Santarém, PA. Brazil.

3 Federal University of Goiás. Special Academic Unit of Biological Sciences. Jataí, GO. Brazil.

Received: 14 September 2018 Accepted: 09 May 2019

How to cite this article Gouvêa-e-Silva LF, Lima CNS, Fernandes KTL, Takanashi SYL, Xavier MB. Quality of life and manual strength in HIV patients diagnosed with neurotoxoplasmosis. Rev Bras Cineantropom Desempenho Hum 2019, 21:e59185. D0l: http://dx.doi. org/10.1590/1980-0037.2019v21e59185

Copyright: This work is licensed under a Creative Commons Attribution 4.0 International License. 


\section{INTRODUCTION}

Human immunodeficiency virus (HIV) infection and its clinical manifestation in the advanced stage, or acquired immunodeficiency syndrome (AIDS) are still considered a public health problem of great relevance due to its pandemic character and its transcendence. According to the Brazilian Epidemiological Bulletin, from 2007 to June 2017, 194,217 cases of HIV infection were reported in Sinan in Brazil ${ }^{1}$.

HIV mortality has greatly reduced with advances in antiretroviral therapy (ART), so a person can live 25 years or more. About $50 \%$ of all cases die from non-HIV-related causes. Currently, HIV cases are managed as a treatment for chronic disease with increased life expectancy, although it may present multiple comorbidities ${ }^{2}$.

Among the most common alterations in patients with AIDS, toxoplasmosis of the central nervous system caused by protozoan Toxoplasma gondii stands out, which is responsible for a large number of focal brain lesions ${ }^{3}$. Clinical manifestations depend on the location and extent of the lesion, often manifesting as diffuse encephalitis, meningoencephalitis or, more often, as a mass affect tumor lesion ${ }^{4}$. Motor dysfunction caused by hemiparesis is due to muscle weakness, motor control, balance, sensory deficit and postural tone abnormalities ${ }^{5}$.

There is a significant proportion of people living with HIV/Aids who have limitations, and loss of muscle mass is one of the most important $t^{6,7}$. Therefore, muscular hypotrophy, fatigue and weakness are factors that can induce depression and reduce quality of life ${ }^{8}$.

In this perspective, it should be emphasized that understanding the quality of life and the handgrip strength related to people living with HIV/Aids represents an important instrument for their approach in the field of health care ${ }^{9}$.

Therefore, the present study aimed to evaluate the handgrip strength and quality of life in HIV-infected patients diagnosed for neurotoxoplasmosis.

\section{METHOD}

This cross-sectional study consisted of $40 \mathrm{HIV-infected} \mathrm{patients} \mathrm{of} \mathrm{both}$ genders aged $23-62$ years (36.90 \pm 8.18 years). Patients were divided into two groups: NT ( $\mathrm{n}=20)$ patients with diagnosis for neurotoxoplasmosis; SNT $(n=20)$ patients without diagnosis for neurotoxoplasmosis. All were attended at the Testing and Counseling Center-CTA/SAE, located in the municipality of Santarém - PA. Data were collected in the form of interviews, physical evaluation and medical records, as well as information such as age, gender, schooling, income, medications used, time of HIV infection diagnosis, diagnosis for neurotoxoplasmosis and TCD4 lymphocyte values.

Information collected was carried out in the first half of 2014 and the study was approved by the Ethics Committee for Research with Human Beings of the Department of Tropical Medicine - Federal University of 
Pará, under CAAE number: 27162514.9.0000.5172 and with the signing of the Free and Informed Consent Form by all survey participants.

A calibrated analogue scale (Welmy Indústria Comércio, Santa Bárbara D'Oeste, SP, Brazil) with accuracy of $100 \mathrm{~g}$ was used to perform body mass measurements, and for height, stadiometer with accuracy of $0.5 \mathrm{~cm}$ was used. Body mass index (BMI) was calculated by dividing body mass by squared height.

Body composition was measured using the four-pole bioimpedance apparatus (Maltron International Ltd, model BF 900, Rayleigh, Essex, England), where fat percentage value was obtained and used for lean mass and fat mass calculations.

Handgrip strength was measured using a dynamometer (Kratos Equipamentos Industriais, Modelo ZM, Cotia - SP, Brazil, accuracy of $1 \mathrm{~kg}$ ), in which the highest value of three attempts for each hand was considered as the result ${ }^{10}$.

To evaluate patients' quality of life, HAT/QoL (HIV/Aids - Targeted Quality of Life Instrument), an instrument prepared by Holmes and Shea ${ }^{11}$ and validated for the Brazilian population ${ }^{12}$ was used.

Values adopted as adequate for handgrip strength were those described by Caporrino et al. ${ }^{13}$; for TCD4 lymphocyte count, those of Scherzer et al. ${ }^{14}$, which is $\leq 200$ cells $/ \mathrm{mm}^{3}$, and for quality of life, the score of $\leq 50$ points was adopted.

Data were grouped and tabulated using the Excel software. Subsequently, descriptive statistics were performed to verify mean, standard deviation, relative frequency, minimum and maximum values. After the normality test (Shapiro-Wilk), inferential statistics were performed using the unpaired t-test to perform comparisons between groups for parametric data, and the Mann-Whitney test, for non-parametric data.

To perform associations, the Chi-square test was used, which when significant, the Odds Ratio was applied. The BioEstat 5.0 software was used, with significance level of $\mathrm{p}<0.05$ for statistical tests.

\section{RESULTS}

Table 1 shows the sociodemographic and clinical characteristics of study participants regarding gender, age, schooling, ethnicity, marital status, family income, immunodeficiency status and use of protease inhibitor.

It is also noteworthy that the mean time of HIV diagnosis in the NT group was $49.40 \pm 42.39$ months; for the neurotoxoplasmosis diagnosis, $42.10 \pm 31.85$ months and for the ART use (antiretroviral therapy) was $47.40 \pm 42.05$ months. For SNT, the mean time of HIV diagnosis was 51.55 \pm 35.45 months and the mean time of ART use was $37.95 \pm 34.88$ months.

Analysis of epidemiological and clinical variables (gender, age, schooling, ethnicity, income, use of protease inhibitor, time of HIV diagnosis and use of antiretroviral therapy) showed no association with the presence or absence of neurotoxoplasmosis ( $p>0.05)$. 
Table 1. Sociodemographic and clinical characteristics of patients with HIV/Aids treated at Santarém-PA

\begin{tabular}{|c|c|c|c|c|c|}
\hline & \multirow{2}{*}{ Variable } & \multicolumn{2}{|c|}{ NT } & \multicolumn{2}{|c|}{ SNT } \\
\hline & & $\mathrm{n}$ & $\%$ & $\mathrm{n}$ & $\%$ \\
\hline \multicolumn{6}{|l|}{ Gender } \\
\hline & Male & 16 & 80 & 14 & 70 \\
\hline & Female & 4 & 20 & 6 & 30 \\
\hline \multicolumn{6}{|c|}{ Age (years) } \\
\hline & $23|-| 32$ & 5 & 25 & 5 & 25 \\
\hline & $33|-| 42$ & 10 & 50 & 11 & 55 \\
\hline & $43|-| 52$ & 4 & 20 & 3 & 15 \\
\hline & $53|-| 62$ & 1 & 5 & 1 & 5 \\
\hline \multicolumn{6}{|c|}{ Schooling (years of school) } \\
\hline & None & 0 & 0 & 0 & 0 \\
\hline & 1 to 3 & 1 & 5 & 1 & 5 \\
\hline & 4 to 7 & 5 & 25 & 9 & 45 \\
\hline & 8 to 11 & 8 & 40 & 3 & 15 \\
\hline & 12 or more & 6 & 30 & 7 & 35 \\
\hline \multicolumn{6}{|c|}{ Ethnicity } \\
\hline & Yellow & 1 & 5 & 0 & 0 \\
\hline & White & 5 & 25 & 6 & 30 \\
\hline & Indigenous & 0 & 0 & 0 & 0 \\
\hline & Brown & 12 & 60 & 12 & 60 \\
\hline & Black & 2 & 10 & 2 & 10 \\
\hline \multicolumn{6}{|c|}{ Marital status } \\
\hline & Married / Living together & 6 & 30 & 9 & 45 \\
\hline & Single & 12 & 60 & 10 & 50 \\
\hline & Divorced & 1 & 5 & 0 & 0 \\
\hline & Widower & 1 & 5 & 1 & 5 \\
\hline \multicolumn{6}{|c|}{ Income (minimum wage ${ }^{\star}$ ) } \\
\hline & Less than 1 & 4 & 20 & 3 & 15 \\
\hline & 1 to 2 & 13 & 65 & 13 & 65 \\
\hline & 3 to 4 & 1 & 5 & 2 & 10 \\
\hline & 5 or more & 2 & 10 & 2 & 10 \\
\hline \multicolumn{6}{|c|}{ Immunodeficiency status } \\
\hline & HIV & 0 & 0 & 10 & 50 \\
\hline & Aids & 20 & 100 & 10 & 50 \\
\hline \multicolumn{6}{|c|}{ Use of Protease Inhibitor } \\
\hline & Yes & 6 & 30 & 7 & 35 \\
\hline & No & 14 & 70 & 13 & 65 \\
\hline
\end{tabular}

Note. NT - Neurotoxoplasmosis; SNT - Without neurotoxoplasmosis; * Minimum wage of R\$ 724,00 was adopted.

Table 2 shows the analysis of the association of CD4 lymphocytes, handgrip strength and quality of life of individuals with or without neurotoxoplasmosis. The results showed no significant association, but attention is drawn to higher percentages in the NT group for inadequate classifications, especially for handgrip strength (75\% vs $45 \%)$.

ART administration (antiretroviral therapy) in the neurotoxoplasmosis group occurred in $95 \%$ of patients. In addition, for those who used the medication, adherence was $70 \%$. In the group without neurotoxoplasmosis, the use of ART occurred in $90 \%$ of patients and adhesion was $29 \%$. 
Table 2. Association of the presence of neurotoxoplasmosis diagnosis with the concentration of TCD4 lymphocytes, handgrip strength and quality of life.

\begin{tabular}{|c|c|c|c|c|c|c|}
\hline \multirow{2}{*}{ Variables } & \multicolumn{2}{|c|}{ NT } & \multicolumn{2}{|c|}{ SNT } & \multirow{2}{*}{$\mathrm{p}$} & \multirow{2}{*}{$\mathrm{OR}$} \\
\hline & $\mathrm{n}$ & $\%$ & $\mathrm{n}$ & $\%$ & & \\
\hline \multicolumn{7}{|c|}{ TCD4 lymphocytes } \\
\hline Adequate & 15 & 79 & 17 & 89 & \multirow{2}{*}{$>0.05$} & \multirow{2}{*}{---} \\
\hline Inadequate & 4 & 21 & 2 & 11 & & \\
\hline \multicolumn{7}{|c|}{ Handgrip strength of right hand } \\
\hline Adequate & 2 & 10 & 3 & 15 & \multirow{2}{*}{$>0.05$} & \multirow{2}{*}{---} \\
\hline Inadequate & 18 & 90 & 17 & 85 & & \\
\hline \multicolumn{7}{|c|}{ Handgrip strength of left hand } \\
\hline Adequate & 5 & 25 & 11 & 55 & \multirow{2}{*}{$>0.05$} & \multirow{2}{*}{---} \\
\hline Inadequate & 15 & 75 & 9 & 45 & & \\
\hline \multicolumn{7}{|l|}{ Quality of life } \\
\hline Adequate & 13 & 72 & 19 & 95 & \multirow{2}{*}{$>0.05$} & \multirow{2}{*}{---} \\
\hline Inadequate & 5 & 28 & 1 & 5 & & \\
\hline
\end{tabular}

Note. NT - Neurotoxoplasmosis; SNT - Without neurotoxoplasmosis; OR - Odds ratio.

Table 3 shows that the comparative analysis of the handgrip strength of patients with and without neurotoxoplasmosis was not significant ( $p$ > 0.05). However, it was observed that the absolute value of the handgrip strength of right hand was $15 \%$ lower in the NT group (35.50 vs. 30.30 $\mathrm{kg}$ ) and the handgrip strength of left hand was $17 \%$ lower in the NT group (36.30 vs $30.26 \mathrm{Kg}$ ), compared to SNT. The association of the presence or absence of neurotoxoplasmosis with handgrip strength did not show significance $(p>0.05)$.

Table 3. Comparison of handgrip strength values in relation to patients with and without Neurotoxoplasmosis.

\begin{tabular}{lcccc}
\hline & Minimum & Maximum & Mean & sd \\
\hline NT & 14 & 49 & 30.30 & 11.23 \\
HSr (Kg) & 5 & 54 & 30.26 & 14.33 \\
HSI (Kg) & & & & \\
SNT & 22 & 55 & 35.50 & 10.07 \\
HSr (Kg) & 23 & 55 & 36.30 & 9.80 \\
HSI (Kg) & & & & \\
\hline
\end{tabular}

Note. NT - Neurotoxoplasmosis; SNT - Without neurotoxoplasmosis; HSr -handgrip strength of right hand; $\mathrm{HSI}$ - handgrip strength of left hand.

Quality of life, through its domains, is presented and compared between groups in Table 4. When comparing domains between groups with and without neurotoxoplasmosis, it was observed that the financial concern presented better index in the group without neurotoxoplasmosis $(p=0.0379)$. However, the other domains showed no statistical difference, but the scores were higher in the SNT group, except for the professional confidence, which was higher in the NT group. The difference between groups of $41 \%$ and $34 \%$ groups in the financial concern and HIV acceptance domains, 
respectively, attracts attention, where the NT group has lower score (p> 0.05). The mean score of domains, as each domain individually, were not associated with the presence or absence of neurotoxoplasmosis ( $p>0.05)$.

Table 4. Comparison of quality of life domains in relation to patients with and without Neurotoxoplasmosis.

\begin{tabular}{cllllllllll}
\hline \multicolumn{1}{c}{ GF } & SL & HC & FC & CM & HIVA & CC & PC & SF & Mean \\
\hline NT & & & & & & & & & & \\
Mean & 63.02 & 74.07 & 55.67 & $33.31^{*}$ & 72.65 & 36.89 & 30.83 & 94.00 & 58.39 & 57.55 \\
Sd & 20.97 & 20.21 & 34.43 & 34.54 & 29.53 & 32.44 & 30.21 & 12.42 & 45.57 & 16.72 \\
SNT & & & & & & & & & & \\
Mean & 72.52 & 79.16 & 66.05 & 56.27 & 78.24 & 56.45 & 35.00 & 89.55 & 68.90 & 66.59 \\
sd & 17.61 & 16.64 & 32.79 & 32.23 & 19.28 & 35.68 & 24.06 & 14.04 & 34.50 & 14.23 \\
$\Delta \%$ & -13 & -6 & -16 & -41 & -7 & -34 & -12 & 5 & -15 & -14 \\
\hline
\end{tabular}

Note. NT - Neurotoxoplasmosis; SNT - Without neurotoxoplasmosis; GF - general function; SL - satisfaction with life; HC - health concern ; FC - financial concern; CM - concern with medication; HIVA - HIV acceptance; CC - confidentiality concern; PC - professional confidence; SF - sexual function; * Statistical difference of group without neurotoxoplasmosis; $p<0.05$.

\section{DISCUSSION}

The aim of this study was to evaluate the handgrip strength and quality of life of HIV-infected patients diagnosed for neurotoxoplasmosis. Due to the scarcity and difficulties of finding studies on neurotoxoplasmosis, most articles discussed here addressed only HIV infection.

Regarding the sociodemographic profile, the study found that in both groups, males obtained higher frequency, a profile observed in studies performed with HIV-infected patients without neurotoxoplasmosis ${ }^{8,15}$.

The Brazilian Epidemiological Bulletin ${ }^{1}$ points out that the majority of cases of HIV infection are in the age group of 20-34 years, corresponding to $52.5 \%$ of cases. In the present study, the most frequent age group in both groups was 33-42 years.

Regarding ethnicity, both groups had predominance of brown ethnicity (60\%), which corroborates the Epidemiological Bulletin ${ }^{1}$, where $45.4 \%$ of individuals described themselves as brown. Another study carried out with HIV/Aids patients from the western region of Pará also reported that the predominant ethnicity was brown.

Regarding the immunodeficiency situation of patients, all patients from group with neurotoxoplasmosis had Aids and half of the SNT group developed Aids. The emergence of the side effects of ART makes many patients discontinue the use of the medication, leaving them prone to opportunistic infections, among them toxoplasmosis/neurotoxoplasmosis ${ }^{17,18}$. Toxoplasmosis is the leading cause of central nervous system (CNS) damage in Aids. Typically, lesions found in the brain present effects that dominate clinical presentation ${ }^{19}$. A study with 250 patients in southern Brazil showed that there is a high risk of serious clinical toxoplasmosis in the study population both due to the reactivation of infection in seropositive patients who do not use regular ART and to the primary infection of seronegative patients, often due to misinformation about the forms of infection ${ }^{20}$. The early introduction of ART improves survival and reduces relapses of cerebral toxoplasmosis ${ }^{21}$. 
The use of protease inhibitor was present in 30\% of patients with neurotoxoplasmosis and in 35\% of SNT. The use of a protease inhibitor in ART with two nucleoside reverse transcriptase inhibitors is the second treatment line, being highly effective in reducing the plasma viral load of RNA/HIV- $1^{17}$. Although the use of the protease inhibitor was similar in both groups, $85 \%$ of TCD 4 lymphocytes were adequate in the SNT group, possibly due to the use of the therapy, which inhibits viral replication and delays the progression of immunodeficiency ${ }^{18}$.

Another study evaluated the incidence and risk factors for neurotoxoplasmosis in two periods before and after the availability of protease inhibitors and observed the efficacy of cotrimoxazole prophylaxis in protection against neurotoxoplasmosis with an additional protective effect of ART. However, the discontinuation of cotrimoxazole use causes deleterious effects to immunodeficient patients ${ }^{22}$.

When comparing handgrip strength between groups, no statistical difference was observed; however, values were $15 \%$ lower in the right limb and $17 \%$ lower in the left limb for NT. This finding is in line with the study by Raso et al. ${ }^{23}$, who compared torque strength among HIV-infected patients who had TCD4 lymphocyte counts above and below $200 \mathrm{cells} / \mathrm{mm}^{3}$, all of them male. It was observed that in patients with TCD4 lymphocytes below 200 cells $/ \mathrm{mm}^{3}$, torque strength was $20 \%$ lower.

Between 2009 and 2013, 138 individuals, most of them female, were evaluated to characterize the physical symptoms of individuals with HIV/ Aids from the physiotherapeutic point of view, and the most common comorbidity was neurotoxoplasmosis, and frequent physical complaints were hemiparesis, pain, altered muscle tone and lipodystrophy ${ }^{24}$.

Another study conducted in Germany also reported that neurotoxoplasmosis is the most important opportunistic infection of the central nervous system in patients infected with human immunodeficiency virus (HIV) and showed that neurotoxoplasmosis occurs mainly in HIV untreated patients, after analyzing the clinical characteristics of all patients diagnosed with neurotoxoplasmosis $(n=140)$, showing that neurological deficits were present in $37 \%$ of them ${ }^{25}$.

The incidence of mortality due to neurotoxoplasmosis decreased substantially during the antiretroviral therapy era, especially when the patient survived the first year of HIV infection and the first three months of neurotoxoplasmosis. As a result, individuals diagnosed with HIV or neurotoxoplasmosis during the ART era could be considered as with low risk of mortality. Therefore, early HIV diagnosis and ART initiation are of paramount importance ${ }^{26}$.

Thus, adherence to ART in addition to improving clinical outcomes and controlling disease progression, also results in better quality of life for patients ${ }^{27}$. This study showed lower scores for the confidentiality concern domain and higher scores for the professional confidence domain in both groups, which can also be observed in studies by Galvão et al. ${ }^{28}$ and Lopes et al. ${ }^{29}$.

The study presents as limitation a large range in the age group, as well as 
a limited number of patients and the absence of a control group without HIV infection. For better reliability of evaluations, DEXA (Dual-energy X-ray Densitometry) could be used to evaluate body composition, as well as electromyography and load cell resources to evaluate muscle activity and strength.

\section{CONCLUSION}

According to the method proposed, the handgrip strength of patients with and without neurotoxoplasmosis was statistically similar, but higher values for the group without neurotoxoplasmosis were observed. The financial concern domain had higher score in the group without neurotoxoplasmosis and confidentiality concern and professional confidence domains were those that showed the lowest and highest scores, respectively, in both groups. Therefore, the presence of neurotoxoplasmosis in the context of Aids and in the use of ART did not affect the handgrip strength and quality of life of people living with the disease. Other conditions associated with AIDS may already interfere with quality of life and handgrip strength.

Further studies should be carried out to better understand the clinical, motor/sensory and epidemiological profile of patients infected with HIV/ Aids diagnosed with neurotoxoplasmosis and, thus, provide better procedures for prevention, orientation and treatment of these patients.

\section{COMPLIANCE WITH ETHICAL STANDARDS}

\section{Funding}

This study received scientific initiation grant from the State University of Pará.

\section{Ethical approval}

Ethical approval was obtained from the local Human Research Ethics Committee - Federal University of Pará and protocol (576.771) was written in accordance with standards set by the Declaration of Helsinki.

\section{Conflict of interest statement}

The authors have no conflict of interests to declare.

\section{Author Contributions}

Conceived and designed experiments: LFGS and MBX. Performed experiments: LFGS, CNSL and KTLF. Analyzed data: LFGS, SYLT and MBX. Contributed with reagents/materials/analysis tools: LFGS, CNSL, SYLT and KTLF. Wrote the paper: LFGS, SYLT and MBX.

\section{REFERENCES}

1. Brasil, Ministério da saúde. Secretaria de Vigilância em Saúde. Boletim epidemiológico AIDS e IST. Brasília, 2017. Disponível em: <http://www.aids.gov.br.> [19/12/2017].

2. Bavinger C, Bendavid E, Niehaus K, Olshen RA, Olkin I, Sundaram V, et al. Risk of Cardiovascular Disease from Antiretroviral Therapy for HIV: A Systematic Review. Plos one 2013; 8(3): e595-51. 
3. Santos IP, Martins FS, Rech G, Rosa BL, Borba Júnior AM. Déficit neurológico focal e confusão mental em paciente imunossuprimido. Rev Epidemiol Control Infect 2013; 3(3):108-9.

4. Soares MT, Pinheiro JBF, Freitas CHSM, Smith AZF, Moreira EFR. Prevalência das coinfecções em pacientes notificados com Aids no Centro de Referência na Paraíba. Rev Bras Ciênc Saúde 2014; 18(Suppl 1):5-12.

5. Alferes DC, Ribeiro MA. Toxoplasmose cerebral: um caso clínico. Rev Científica Acad Força Aérea 2012; (2):96-111.

6. Bauer LO, Ceballos NA, Shanley JD. Sensorimotor dysfunction in HIV/ AIDS: effects of antiretroviral treatment and comorbid disorders. AIDS 2005; 19(1):495-502.

7. Van ASM, Myezwa H, Stewart A. The International Classification of Function Disability and Health (ICF) in adults visiting the HIV outpatient clinic at a regional hospital in Johannesburg, South Africa. AIDS Care 2009; 21:50-58.

8. Bopp CM, Phillips KD, Fulk LJ, Hand GA. Clinical implications of therapeutic exercise in HIV/AIDS. J Assoc Nurses AIDS Care 2003;14(1): 73-8.

9. Brasil, Ministério da Saúde. Secretaria de Vigilância em Saúde. Departamento de DST e Aids e Hepatites Virais. Protocolo clínico e diretrizes terapêuticas para adultos vivendo com HIV/AIDS. Brasília (DF): Mi`nistério da Saúde. 2013. Disponível em:< http://www.aids.gov.br/pt-br/pub/2013/protocolo-clinico-e-diretrizes-terapeuticas-para-manejo-da-infeccao-pelo-hiv-em-adultos> [05/02/2017].

10. Fernandes Filho J. A prática da avaliação física. 2.ed. Rio de Janeiro: Shape. 2003.

11. Holmes WC, Shea JA. A new HIV/Aids - targeted quality of life (HAT-QoL) instrument. Development, reliability, and validity. Med Care 1998; 36(2):138-54.

12. Soárez PC, Castelo A, Abrão P, Holmes WC, Ciconelli RM. Tradução e validação de um questionário de avaliação de qualidade de vida em Aids no Brasil. Rev Panam Salud Publica 2009; 25(1):69-76.

13. Caporrino FA, Faloppa F, Santos JBG, Réssio C, Soares FHC, Nakachima LR, et al. Estudo populacional da força de preensão palmar com dinamômetro JAMAR. Rev Bras Ortopedia 1998; 33(2):150-154.

14. Scherzer R, Heymsfield SB, Lee D, Powderly WG, Tien PC, Bacchetti P, et al. Decreased limb muscle and increased central adiposity are associated with 5 year all cause mortality in HIV infection. AIDS 2011; 25:1405-1414.

15. Araújo TM, Barros LM, Caetano JA, Moreira RAN, Frota NM, Feitosa ACL, et al. Neurotoxoplasmose em pacientes com HIV/Aids internados em unidade de terapia intensiva. Rev enferm UFPE 2012; 6(5):1046-52.

16. Gouvêa-e-Silva LF, Lima, DD, Alves, MRS, Xavier, MB. Risco cardiovascular em pessoas vivendo com o HIV/Aids e sua associação com o nível de atividade física e o tempo de terapia antirretroviral. In: Meneguetti DUO, Silva RPM, organizadores. Ciência da Saúde na Amazônia Ocidental. Rio Branco, Acre: Stricto Sensu; 2019. p.64-79.

17. Brasil, Ministério da Saúde. Protocolo clínico e diretrizes terapêuticas para manejo da infecção pelo HIV em adultos. Brasília (DF): Ministério da Saúde. 2013. Disponível em:< http://www.aids.gov.br/pt-br/pub/2013/protocolo-clinico-e-diretrizes-terapeuticas-para-manejo-da-infeccao-pelo-hiv-em-adultos> [14/04/2017].

18. Fukumoto AECG, Oliveira CC, Tasca KI, Souza LR. Evolution of patients with aids after cART: clinical and laboratory evolution of patientes with aids after 48 weeks of antirretroviral treatment. Rev Inst Med Trop Sao Paulo 2013; 55(4):267-273.

19. Chimelli L, Rosemberg S, Hahn MD, Lopes MB, Netto MB. Pathology of the central nervous system in patients infected with the human immunodeficiency virus (HIV): a report of 252 autopsy cases from Brazil. Neuropath Appl Neurobiol 1992;18: 478-488.

20. Xavier GA, Cademartori BG, Cunha Filho NA, Farias NAR. Avaliação soroepidemiológica de toxoplasmose em pacientes HIV/SIDA no sul do Brasil. Rev Inst Med Trop Sao Paulo 2013; 55(1):25-30. 
21. Vidal JE, Hernandez AV, Oliveira ACP, Dauar RF, Barbosa Junior SP, Focaccia R. Cerebral Toxoplasmosis in HIV-Positive Patients in Brazil: Clinical Features and Predictors of Treatment Response in the HAART Era. AIDS Patient Care STDS 2005; 19(10): 626-634.

22. Abgrall S, Rabaud C, Costagliola D. Incidence and Risk Factors for Toxoplasmic Encephalitis in Human Immunodeficiency Virus-Infected Patients before and during the Highly Active Antiretroviral Therapy Era. Clin Infect Dis 2017; 33:1747-55.

23. Raso V, Shephard RJ, Casseb JSR, Duarte AJS, Silva PRS, Greve JM, et al. Association between muscle strength and the cardiopulmonary status of individuals living with HIV/Aids. Clinics 2013; 68(3):359-364.

24. Amorim TB, Santana EP, Santos KOB. Perfil Sintomatológico de indivíduos com HIV/AIDS em um setor de fisioterapia. Fisioter mov 2017; 30(1):107-114.

25. Hoffmann C, Ernst M, Meyer P, Wolf E, Rosenkranz T, Plettenberg A, et al. Evolving characteristics of toxoplasmosis in patients infected with human immunodeficiency virus-1: clinical course and Toxoplasma gondii-specific immune responses. Clin Microbiol Infect 2007; 13: 510-515.

26. Martin-Iguacel R, Ahlstrom MG, Touma M, Engsig FN, Staerke NB, Staerke M et al. Incidence, presentation and outcome of toxoplasmosis in HIV infected in the combination antiretroviral therapy era. J Infect 2017; 75: 263-273.

27. Chiou PY, Kuo BI, Lee MB, Chen YM, Chuang P, Lin LC. Programme of symptom management for improving quality of life and drug adherence in AIDS/HIV patients. J Adv Nurs 2006;55(2):169-9.

28. Galvão MTG, Cerqueira ATAR, Marcondes-Machado J. Avaliação da qualidade de vida de mulheres HIV/Aids através do HAT-QoL. Cad Saude Publica 2004; 20(2):430-437.

29. Lopes PSD, Silva MMG, Torres IC, Stadnik CMB. Qualidade de vida dos pacientes HIV positivo com mais de 50 anos. Rev AMRIGS 2011;55(4):356-360.

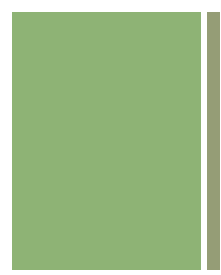

Corresponding author

Luiz Fernando Gouvêa e Silva

Federal University of Goiás / Jataí Regional

Campus Jatobá - University City

Human Anatomy and Comparative Laboratory

BR 364, km 195, no. 3800

CEP 75801-615 - Jataí - G0, Brazil.

Email: Ifgouvea@yahoo.com.br 